\title{
Foreign Language Anxiety and Achievement: Systematic Review
}

\author{
Murad M. Al-Shboul ${ }^{1}$, Ismail Sheikh Ahmad ${ }^{1}$, Mohamad Sahari Nordin ${ }^{1} \&$ Zainurin Abdul Rahman ${ }^{1}$ \\ ${ }^{1}$ Institute of Education, International Islamic University Malaysia, Malaysia \\ Correspondence: Murad M. Al-Shboul, Institute of Education, International Islamic University Malaysia, \\ Malaysia. E-mail: muradshboul@yahoo.com
}

Received: February 6, 2013 Accepted: February 26, 2013 Online Published: March 25, 2013

doi:10.5539/ijel.v3n2p32

URL: http://dx.doi.org/10.5539/ijel.v3n2p32

\begin{abstract}
This systematic review of literature on foreign language anxiety and its relationship with achievement is additional clarification to the earlier works and reviews concerned with this issue. Firstly, it defines the foreign language anxiety concept where eventually foreign language anxiety is differentiated from other related concepts. Secondly, it reviews the existing studies where the constructs of foreign languages are determined. Finally, it presents the studies that concern foreign language anxiety and achievement in a systematic way where different settings, languages, learners' stages and disciplines were involved.
\end{abstract}

Keywords: foreign language anxiety, foreign language anxiety and achievement, systematic review

\section{Introduction}

With increased attention being given to language learners and their affective factors, research in this field has asserted that language anxiety is the most powerful predictor on the students' performance among the affective factors (Liu \& Huang, 2011). Gardner, Tremblay, and Masgoret (1997) investigated the relationship between foreign language anxiety among different affective variables and language performance to declare that foreign language anxiety was ranked as the highest factor which negatively correlated with language achievement. More recently, Olivares-Cuhat (2010) also investigated the relative importance of various learner variables such as cognitive, meta-cognitive and affective variables on foreign/second language performance to assert over again that foreign language anxiety is the important factor in learning a foreign or second language.

The last few decades have witnessed interest in foreign language anxiety in general and foreign language anxiety in association with achievement in particular. Raising the issue of foreign language anxiety and achievement, flux results have been introduced. Inaugural studies showed that foreign language anxiety can be a facilitator. However, scrutinizing the recent literature, a plethora of work has indicated that achievement is hindered by foreign language anxiety which seems to thrust aside the consequences of the early studies.

In Scovel (1978) review, for example, different measures to assess foreign language anxiety were used. Thus, contradictory results were presented. On the other hand, the review of (Horwitz, 2001) declared the negative side of foreign language anxiety on achievement. In the later review, the suitable measure to assess foreign language anxiety was used. However, values and the magnitude of the negative relationship between the two variables were not counted. Moreover, young learners were neglected in the review. One step further; this systematic review, considers more studies in different nations, target languages, stages, and most importantly, it is up-to-date to recognize the change over one decade. It can be straightforward to determine the relationship between foreign language anxiety and achievement, utilizing the appropriate measure to assess foreign language anxiety.

\section{Literature Review}

\subsection{Foreign Language Anxiety Definition}

Anxiety is a central construct in theories of personality. In the 1970, Spielberger, Gorsuch, and Lushene provided a reliable self-report scale to assess anxiety (Spielberger, Reheiser, Owen, \& Sydeman, 2004). According to them, anxiety in general consists of two components or dimensions; state anxiety and trait anxiety. State anxiety has been defined as "consisting of subjective feelings of tension, apprehension, nervousness and worry, with associated arousal of the autonomic nervous system.", and trait anxiety has been defined as "stable individual differences in anxiety proneness in situations perceived as dangerous and threatening." (Mulatu, 2002; 


\section{Spielberger et al., 2004).}

Hence, Horwitz, Horwitz, and Cope (1986, p. 128) have defined foreign language anxiety as "a distinct complex of self-perceptions, beliefs, feelings, and behaviors related to classroom language learning arising from the uniqueness of the language learning process.". It is distinct from general anxiety even though it seems to be comparatively related to the first component of anxiety in which the anxious of second or foreign language learners feel tension, apprehension, nervousness, and worry in some specific situations.

In Horwitz's et al. definition, foreign language anxiety has three components; communication apprehension, test anxiety, and fear of negative evaluation. They defined communication apprehension as "a type of shyness characterized as fear of, or anxiety about communicating with people" (p. 127). It refers to an individual's level of anxiety in communication with others. It is anticipated by those who expect to have troubles in communication with others to likely be in real difficulty to control the situation. Test anxiety is defined as "the type of performance anxiety resulting from a fear of failure in an academic evaluation setting" (p. 127). It refers to the experience of anxiety in foreign language class that students normally face in exams. It is a sensitive situation where students are expected to succeed or failed. Fear of negative evaluation is the "apprehension about others' evaluations, avoidance of evaluative situations" (p. 128). It is somewhat different from test anxiety in which here, fear of negative evaluation may occur in any social evaluation rather than restricted in academic situations.

\subsection{Foreign Language Anxiety}

Since anxiety has been found as a vital factor affecting language learning, it is fundamental to identify students who are anxious in a foreign language class(Horwitz et al., 1986). As a result, Horwitz et al. (1986) have developed a scale to measure the amount of anxiety that students may experience in learning a foreign language. They named the scale "Foreign Language Classroom Anxiety scale" (FLCAS). The theoretical framework consists of the three components: communication apprehension, test anxiety, and fear of negative evaluation. The items were developed from students self-reports who were concerned about their foreign language classes, from clinical experience where the first author has long experience in dealing with anxious students in her own foreign language classes, and from a review of related instruments. The scale has 33 items scored on a 5-point Likert scale ranging from "strongly agree" to "strongly disagree". The possible range of score is $33-165$; the higher score indicates the more anxious students are. Horwitz et al. (1986) applied the scale to 78 students who were concerned about foreign language classes out of 225 English students who were learning Spanish as a foreign language in the beginner language classes at the University of Texas, Austin. The scale has demonstrated internal reliability, achieving an alpha coefficient of .93 with all items. Test-retest reliability over eight weeks yielded an $(\mathrm{r}=.83, \mathrm{p}<.001)$ in two tailed tests.

In another supplementary study to the previous study, Horwitz (1986) construct-validated the measure to establish that foreign language anxiety is a phenomenon related to but distinguishable from other specific anxieties. In the following study, she administered FLCAS to approximately 300 undergraduate foreign language students at the University of Texas in a number of separate studies. A correlation of the FLCAS with other related scales has been conducted. Table 1 below depicts the scale, $p$-value, number of the respondents, variance shared, and the variance not shared between the scales. (See Also Horwitz, 2001).

Table 1. Differentiating foreign language anxiety from other related anxieties

\begin{tabular}{lcccccc}
\hline Scale & $\mathrm{r}$ & $\mathrm{P}$ & $\mathrm{N}$ & $\mathrm{Scale}$ & $\begin{array}{l}\text { Variance } \\
\text { Shared }\end{array}$ & $\begin{array}{l}\text { Variance } \\
\text { Not Shared }\end{array}$ \\
\hline $\begin{array}{l}\text { Trait Scale of the State-Trait } \\
\begin{array}{l}\text { Anxiety Inventory (Spielberger, } \\
\text { 1983) }\end{array}\end{array}$ & .29 & .002 & 108 & FLCAS & $8 \%$ & $92 \%$ \\
\hline $\begin{array}{l}\text { Personal report of communication } \\
\text { apprehension (McCrosky, 1970) }\end{array}$ & .28 & .063 & 44 & FLCAS & $8 \%$ & $92 \%$ \\
\hline $\begin{array}{l}\text { Fear of negative evaluation scale } \\
\text { (Watson \& Friend, 1969) }\end{array}$ & .36 & .007 & 56 & FLCAS & $13 \%$ & $87 \%$ \\
\hline Test anxiety scale (Sarason, 1978) & .53 & .001 & 60 & FLCAS & $28 \%$ & $72 \%$ \\
\hline
\end{tabular}


Different related anxiety scales concurrently with the FLCAS have been administered to find insignificant correlation between the FLCAS and McCroskey (1970) personal report of communication apprehension $(\mathrm{r}=.28$, $\mathrm{p}=.063$ ), and slight significant correlation with Spielberger, Gorsuch, Lushene, Vagg, and Jacobs (1983) inventory of trait scale of the state-trait anxiety $(\mathrm{r}=.29, \mathrm{p}=.002)$, and Watson and Friend (1969) scale of fear of negative evaluation $(\mathrm{r}=.36, \mathrm{p}=.007)$. However, moderate correlation was found between the FLCAS and Watson and Friend (1969) scale of test anxiety $(\mathrm{r}=.53, \mathrm{p}=.001)$. Even though a significant moderate correlation was found between the FLCAS and the test anxiety scale, the variance shared between them was low. That is the variance not shared was reasonable in all measures to discriminate the FLCAS from other related anxieties. Therefore, these results were enough evidence to establish the discriminated validity of the foreign language anxiety from the related other specific anxieties constructs.

Foreign language classroom anxiety scale has been found to be a highly reliable scale to measure foreign language anxiety. In most studies, internal reliability has been demonstrated above (0.92 - 0.95) (Aida, 1994; Cao, 2011; Chen, 2007; Cheng, 1998; Horwitz, 1986; Toth, 2008). In addition to that, Trang (2012) has recently reviewed the Horwitz, Horwitz and Cope's (1986) theory of foreign language classroom anxiety to discuss the criticisms that have been engaged with it since the theory emerged, he concluded that foreign language anxiety is distinctive from other anxieties.

Even though the scale of FLCAS has been widely used in foreign language anxiety measurement, numerous empirical studies have dissimilar findings in terms of the constructs of foreign language anxiety (e.g. Aida, 1994; Burden, 2004; Cao, 2011; Chiang, 2007; Lan, 2010; Lee, 2011; Park \& Lee, 2005; Perez-Paredes \& Martinez-Sanchez, 2000-2001; Sanchez-Herrero \& Sanchez, 1992; Toth, 2008; Zulkifli, 2007). For instance, in Park and Lee (2005) study, they administered a 19-item language anxiety questionnaire to 132 Korean college students who enrolled in English conversation classes. The results of factor analysis indicated that language anxiety comprised of three main components. Also, Lee (2011) explored the relationship between English learning anxiety and communication apprehension, test anxiety, and fear of negative evaluation among 254 non-English major students in Taiwan to support the foreign language anxiety theory. In addition to that, Zulkifli (2007) conducted a study to identified the factors that contribute to foreign language classroom anxiety. A Language anxiety questionnaire was applied based on FLCAS constructs. She concluded that fear of communication, test anxiety, and fears of negative evaluation were the factors that trigger anxiety in foreign language classroom. Furthermore, Toth (2008) adapted FLCAS for the use in the Hungarian EFL context to test the psychometric properties of the new instruments. The results suggests that communication apprehension, fear of inadequate performance in English classes, and attitudes to the English class were all important components which constitute the constructs of foreign language classroom anxiety. Even though the constructs of foreign language anxiety constructs were named differently across the studies, they all support Horwitz, Horwitz and Cope's (1986) theory of foreign language classroom anxiety. Table 2 below depicts the different names across the studies.

Table 2. Constructs of foreign language anxiety across the studies

\begin{tabular}{lllll}
\hline \multirow{2}{*}{ Year } & Author & \multicolumn{2}{l}{ Names of Foreign Language Anxiety Constructs } & \\
\cline { 3 - 5 } & & $\begin{array}{l}\text { Communication } \\
\text { Apprehension }\end{array}$ & Test Anxiety & $\begin{array}{l}\text { Fear of Negative } \\
\text { Evaluation }\end{array}$ \\
\hline 2005 & $\begin{array}{l}\text { Hyesook Park, } \\
\text { Adam R. Lee }\end{array}$ & $\begin{array}{l}\text { Communication } \\
\text { Apprehension }\end{array}$ & $\begin{array}{l}\text { Examination } \\
\text { Anxiety }\end{array}$ & Criticism Anxiety \\
\hline 2011 & Mei-Ling Lee & $\begin{array}{l}\text { Communication } \\
\text { Apprehension }\end{array}$ & Test Anxiety & $\begin{array}{l}\text { Fear of Negative } \\
\text { Evaluation }\end{array}$ \\
\hline 2007 & VovianaZulkifli & Fear of Communication & Test Anxiety & $\begin{array}{l}\text { Fear of Negative } \\
\text { Evaluation }\end{array}$ \\
\hline \multirow{2}{*}{2008} & ZsuzsaToth & $\begin{array}{l}\text { Communication } \\
\text { Apprehension }\end{array}$ & $\begin{array}{l}\text { Fear of } \\
\text { Inadequate } \\
\text { Performance in } \\
\text { English Class }\end{array}$ & $\begin{array}{l}\text { Attitudes to the } \\
\text { English class }\end{array}$ \\
\hline
\end{tabular}


Regardless the majority of the studies have found that foreign language anxiety consist of three constructs, which supports Horwitz, Horwitz and Cope's (1986) theory, some found that foreign language anxiety is actually four constructs and even refute the test anxiety component to conclude that test anxiety is related to general anxiety (Aida, 1994). For example, in Aida's study, she examined the theory of foreign language classroom anxiety by validating an adaptation of FLCAS for non-English students who were learning Japanese language; factor solution had provided partial support to the theory. Four constructs were revealed. However, test anxiety was not included. She claimed that test anxiety is a general anxiety problem. Similarly, Perez-Paredes and Martinez-Sanchez (2000-2001) reduplicated Aida's study to examine the Horwitz, Horwitz and Cope's foreign language anxiety using a large number of Spanish students who learn English language as a foreign language regarding they were homogeneous in term of proficiency and foreign language study profile. Also, the same instrument, research procedures, and statistical tools were all replicated. Likewise, principal component analysis had yielded four constructs. They claimed that FLCAS factors are far from clear, suggesting further research to establish the components of foreign language anxiety.

Due to the flux results showing inconsistent of the number of factors that construct foreign language anxiety, Cao (2011) employed two foreign language anxiety models; three factors model and four factors model to find out which model had better fitness. With a 300 Chinese college students who were learning English as a foreign Language to prove which model of FLCAS is better fit by comparing fit indices. Confirmatory factor analysis showed that the three-model had the best fit. Table 3 below depicts the results of both models.

Table 3. Comparison of fit of the two models of foreign language anxiety

\begin{tabular}{|c|c|c|c|c|c|}
\hline Model & $\begin{array}{l}\text { Chi-square } \\
\left(\mathrm{X}^{2}\right)\end{array}$ & $\begin{array}{l}\text { Root Mean } \\
\text { Square Error } \\
\text { Approximation } \\
\text { (RMSEA) }\end{array}$ & $\begin{array}{l}\text { Akaike } \\
\text { Information } \\
\text { Criterion } \\
\text { (AIC) }\end{array}$ & $\begin{array}{l}\text { Schwatz } \\
\text { Bayesian } \\
\text { Criterion } \\
\text { (SBC) }\end{array}$ & $\begin{array}{l}\text { Brownw-Cudeck } \\
\text { Cross Validation } \\
\text { Index (BCCVI) }\end{array}$ \\
\hline $\begin{array}{l}\text { Three-Factor } \\
\text { Model }\end{array}$ & 2169.18 & .07 & 7.72 & 8.57 & 7.78 \\
\hline $\begin{array}{l}\text { Four-Factor } \\
\text { Model }\end{array}$ & 2211.19 & .07 & 7.88 & 8.77 & 7.93 \\
\hline
\end{tabular}

\subsection{Foreign Language Anxiety and Achievement}

Numerous studies in the field of foreign language anxiety have been conducted to prove that foreign language anxiety has an impact on students' achievement or performance (See Elaine Horwitz, 2001). Reviewing the literature in relation to this issue, there have been consistent reasonable negative relationships between language anxiety and performance or achievement in different contexts with different target languages.

In the early work for Horwitz (1986) significant negative correlation was found between foreign language anxiety and English achievement of students who were learning the Spanish or French languages. The correlation between foreign language anxiety and final grade for intact beginning Spanish classes was $\left(\mathrm{r}={ }^{-} .49\right.$, $\mathrm{p}=.003, \mathrm{n}=35)$ and for two beginning French classes was $\left(\mathrm{r}={ }^{-} .54, \mathrm{p}=.001, \mathrm{n}=32\right)$ expressing that students who experience higher levels of foreign language anxiety receive lower grades in compare to their counterparts.

Similarly with the same context,Phillips (1992) examined the effect of anxiety as measured by FLCAS on students' oral exam performance as measured by test scores and other several performance variables related to accuracy and amount of comprehensible speech. Pearson correlation between FLCAS scores and oral exam performance grades was computed as well as correlations between FLCAS and eight of oral performance variables such as average length of communication units, percentage of total words in communication units, percent of error-free communication units, percentage of total words in error-free communication units, average length of maze, percentage of total words in maze, number of dependent clauses used, and number of target structure used were computed as well. Finding revealed significant, moderate adverse relationship between foreign language anxiety and oral performance in general $(\mathrm{r}=-.40, \mathrm{p}=.01, \mathrm{n}=44)$, also significant negative correlation between FLCAS and average length of communication unit $(\mathrm{r}=-.34, \mathrm{p}=.02)$, percentage of total words in communication units $\left(\mathrm{r}={ }^{-} .38, \mathrm{p}=.01\right)$, number of dependent clauses used $\left(\mathrm{r}={ }^{-} .38, \mathrm{p}=.01\right)$, and number 
of target structure used $(r=-39, p=.01)$, were found with the same sample.

Gardner et al. (1997) investigated the relationship between foreign language anxiety among different affective variables and achievement in French. In their study two measures of achievement were used; objective measures and French grades. Significant negative relationship was recognized in language anxiety and objective measure $\left(\mathrm{r}={ }^{-} .66, \mathrm{p}=.001, \mathrm{n}=102\right)$, and French grades $\left(\mathrm{r}={ }^{-} .33, \mathrm{p}=.01, \mathrm{n}=102\right)$. Besides, foreign language anxiety was ranked as the highest negative correlation with achievement among the other affective variables measured.

In addition to that, Sellers (1999) investigated the relationship between anxiety and reading comprehension, process, and recall in Spanish as a foreign language. Different research techniques used to measure the variables; anxiety scales such as FLCAS and reading anxiety scales were used to measure language anxiety, multiple choice test and written protocol were also used to measure reading comprehension, and a cognitive interference questionnaire and think aloud interviews were used to measure reading process and recall. Findings showed that not only highly anxious students tended to recall less passage content than did those who are less anxious but also highly anxious learners recalled fewer pausal units. Also, results of a cognitive interference questionnaire indicated that highly anxious students tended to experience more off-task, interfering thoughts than their less anxious students.

In reverse context, where Spanish learners learn English as a foreign language, Wilson (2006) posted a question to examine the relations between foreign language anxiety and students' oral performance. In addition to studying the overall scores of the speaking component in relation with foreign language anxiety by taking into account the grammatical accuracy, breadth of vocabulary, pronunciation including individual sounds and word stress, and fluency, eight measures of oral ability in English such as length of communication unit, percentage of total words in communication units, percent of error-free communication units, percentage of total words in error-free communication units, average length of maze, percentage of total words in maze, number of dependent classes used, and number of target structure used for a second time were applied (See Phillips, 1992). Again, correlational analysis between oral tests, the eight criteria variables, and FLCAS scores was carried out. The findings revealed a significant, moderate inverse relationship between foreign language anxiety and oral performance in general $\left(\mathrm{r}={ }^{-} .494, \mathrm{p}=.001, \mathrm{n}=40\right)$, also a significant negative correlation between FLCAS and total words in communication units $\left(\mathrm{r}={ }^{-} .381, \mathrm{p}=.015\right)$ whereas a significant positive correlation between foreign language anxiety and percentage of total words in mazes was found $(\mathrm{r}=.341, \mathrm{p}=.031)$. In a like manner, Hewitt and Stephenson (2011)replicated Phillips' study lately. Not only the exact question was posed to assess the influence of foreign language anxiety by almost the same number of sample size but also the identical procedure and the instruments where FLCAS was used to measure the level of foreign language anxiety and the oral performance instrument with the eight variables used originally by Phillips to measure the oral ability in a foreign language were involved. Certainly, significant negative relationship was found between foreign language anxiety and oral performance $(r=-.49, \mathrm{p}=.001)$, suggesting that students who showed high anxiety levels in foreign language anxiety did more poorly on the oral performance than did those who show low anxiety levels in language anxiety. Consistent with the previous study, only one variable of the eight oral performance criteria were negatively significant; the variable of total words in communication units $(r=-.38, p=.015)$.

In spite of the confused results with some specific variables related to the oral performance criteria, congruent results confirmed that oral ability in foreign language has been influenced by foreign language anxiety regardless of the publication issues (Note 1). Table 4 below summarizes the statistical results of the Person correlation for overall performance, the eight criteria and foreign language classroom anxiety scale scores that are duplicated in the three studies. 
Table 4. Summary of the statistical results of the duplicated studies

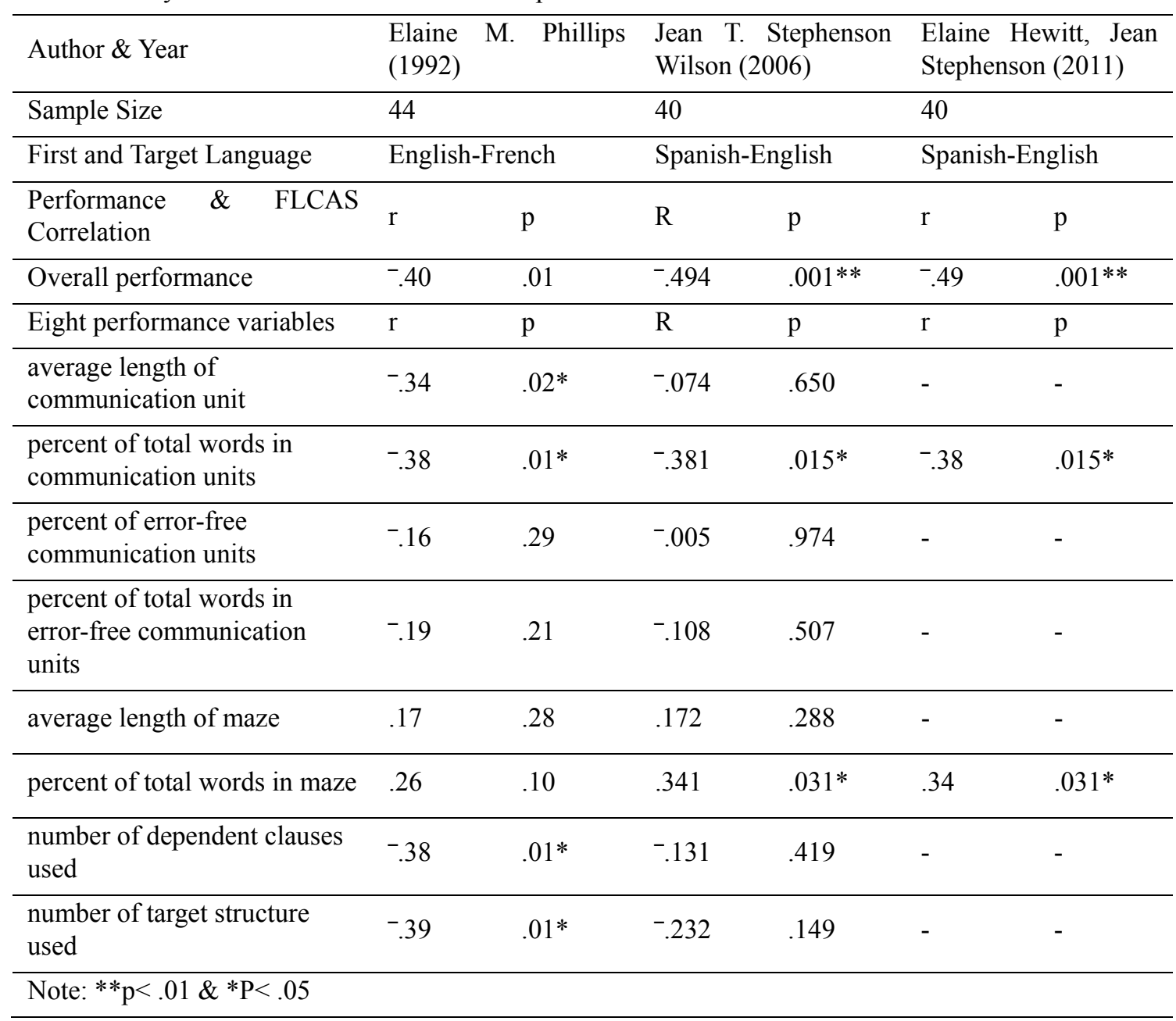

Empirical studies not only showed that university students have been affected by foreign language anxiety but also school students are also affected. With the same context of the target language; sixth, seventh and eighth Spanish grader school students were employed to examine the relationship between foreign language anxiety and students' performance on numeral English achievement measures (Sanchez-Herrero \& Sanchez, 1992). Yet again, significant negative correlations were found between foreign language anxiety and achievement in different groups with different English achievement tests (Sanchez-Herrero \& Sanchez, 1992).

In different contexts, where different language learners who learn English language as a foreign language, studies with Turkish, Korean, Pakistani, Arabic, Polish, Persian, Thai, and Chinese have been conducted. In the Turkish setting, Batumlu and Erden (2007) conducted a study to find out whether foreign language anxiety and students' English achievement had any relationship or not. For the purpose of the study, FLCAS was administered to determine the students' foreign language anxiety levels for 150 university students with concern of the representation of the general population whereas the average of students' first and second midterms was also used to assess the students' foreign language achievement. Analysis of correlation proved a significant negative relationship between foreign language anxiety and English achievement $(r=-.45, \mathrm{p}=.01, \mathrm{n}=150)$.

Likewise, Dalkilic (2001) investigated the relation between the students' foreign language anxiety levels and their achievement in speaking course. Mean scores of FLCAS have been aggregated and compared to the students' overall grades in speaking course to reveal that foreign language anxiety correlated negatively with the students' speaking achievement, representing that the grades of the students turn out to be higher as their level of language anxiety increased.

In the Korean situation, Park and Lee (2005) also examined the relationship between language anxiety and oral performance. Results showed a significant negative correlation between anxiety and oral performance $\left(\mathrm{r}={ }^{-} .321\right.$, $\mathrm{p}=.001, \mathrm{n}=132)$. 
In the Pakistani context, the relationship between foreign classroom language anxiety and students' academic achievement with university students was investigated (Awan, Azher, Nadeem, \& Naz, 2010). FLCAS was used to assess English language anxiety, and the students' grade point average in English classes was taken in consideration. Pearson correlation analysis exposed significant negative correlations between the two variables $\left(\mathrm{r}={ }^{-} .273, \mathrm{p}=.001, \mathrm{n}=149\right)$.

In the Arabic setting, Abu-Ghararah (1999) conducted a study to determine the effect of foreign language anxiety on English achievement. Using FLCAS and students' grades of 240 secondary and university students, a harmonious negative correlation was found between foreign language anxiety and the students' English achievement in general. Moreover, a negative correlation was found between foreign language anxiety and students' achievement within the group of secondary and university students.

In the Polish situation, Szyszka (2011) hypothesized that foreign language anxiety negatively correlated with self-perceived competence as one of the integral components of oral performance. For the purpose of the investigation link between foreign language anxiety and the self-perceived levels of pronunciation, FLCAS to measure the level of language anxiety and a pronunciation self-evaluation form to measure the participants' self-perceived overall level of pronunciation competence in general and the level of aspects of their segmental pronunciation such as vowels and consonants and super-segmental elements such as pronunciation of individual words, words stress, weak forms, rhythm, linking, assimilation, and intonation were administered to 48 teacher training college students. Pearson Product Moment correlation scores of the pronunciation self-perception questionnaire were calculated to indicate a quite significant strong negative relationship between foreign language anxiety and self-perceived competence of pronunciation $\left(\mathrm{r}={ }^{-} .54, \mathrm{p}=.01, \mathrm{n}=48\right)$ to confirm that students who demonstrated higher levels of foreign language anxiety tended to declare lower pronunciation competence. Further, Spearman's rho correlation was run to examine the relationship between foreign language anxiety and the other self-perceived aspects to conclude that apart from intonation, all segmental and super-segmental were found significantly and adversely correlated with foreign language anxiety.

In the Iranian situation, different language skills were studied in relationship to foreign language anxiety. However, as the previous study, almost the same negative correlation value was found in this environment between foreign language anxiety and the listening comprehension skill as a receptive skill. Atasheneh and Izadi (2012) tested the relationship between foreign language anxiety and listening comprehension. 60 out of 120 intermediate Persian students based on the proficiency test who were learning English as a foreign language in the field of English translation were selected to participate in the study. FLCAS and two listening comprehension tests were implemented in the inquiry. Using correlation analysis with the homogenous sample, a significant, moderate negative relationship was found between the two variables $(r=-.469, p=.000, n=60)$.

In the Thai context, 318 middle school students in an English language program were employed to investigate the relationship between foreign language anxiety and students' performance. Results gained revealed significant, moderate negative relationship between foreign language anxiety and performance in English language $\left(\mathrm{r}={ }^{-} .283\right.$, $\mathrm{p}=.01, \mathrm{n}=318$ ), (Anyadubalu, 2010).

Clearly studies on Chinese learners who learn English as a foreign language were the dominant in this area of study. Plethora of work concerning language anxiety and achievement has been conducted in the Chinese environment. For instance, in Lu and Liu (2011) study, they measured foreign language anxiety in relation with students' performance in English. With a large sample size of diverse disciplines from three universities in China where students enrolled in compulsory English courses offered by the universities, a significant, moderate negative relationship were found between foreign language anxiety measured by FLCAS and English performance measured by aggregated scores in the course final exam $(r=-.317, \mathrm{p}=.01, \mathrm{n}=934)$, concluding that lessened language anxiety is an essential element for enhancing students' learning outcomes. Similarly, Zheng (2010) examined language anxiety in relation with test performance in English. Again with a large sample size recruited from students who were taking College English Test in a Chinese university, results of structural equation modeling exhibited that language anxiety had negative impact on achievement $\left(\mathrm{r}={ }^{-} .45, \mathrm{p}=.01, \mathrm{n}=830\right)$.

In the relationship between foreign language anxiety and a specific language learning skill, Yao and Jingna (2011) carried out a study to find out the relationship between foreign language anxiety level and reading comprehension proficiency. 92 students from the school of Agricultural and Food Engendering in a Chinese University were selected randomly. Using FLCAS to measure foreign language anxiety and a test which includes three passages to measure reading and comprehension proficiency, the Pearson Product-Moment correlation results showed a significant, moderated negative relationship between anxiety and test scores in reading comprehension $\left(\mathrm{r}={ }^{-} .346, \mathrm{p}=.001, \mathrm{n}=92\right)$, indicating that lower scores in reading and comprehension proficiency 
test are most likely received if the students' level of foreign language anxiety is higher.

Concerning English major students, Kao and Craigie (2010) employed 101 undergraduate Mandarin students from the department of Applied English in a Chinese university. To examine the relationship between foreign language anxiety and the participants' English course achievement, FLCAS scores and self-reported data based on the students' academic results scores of the English course were considered to conclude that foreign language anxiety had a significant negative effect on English achievement. Further, Cheng (2005) investigated the relationship between foreign language anxiety and English oral conversation course semester achievement. 253 Chinese students who are majored in English language were selected. Again, significant negative correlation was found between foreign language anxiety and English oral conversation course semester as measured by FLCAS and final scores of oral English $\left(\mathrm{r}={ }^{-} .174, \mathrm{p}=.001, \mathrm{n}=253\right)$.

Scrutinizing the literature with reference to this focus, there were two studies where the same results were displayed. In Cheng, Horwitz, and Schallert (1999) and Cheng (1998), the same sample size of 433 Taiwanese English major students who were taking speaking and writing classes were accessibly chosen to investigate the relationship between foreign language anxiety and achievement. Negative correlation was established between FLCAS and English achievement in speaking and writing course grades with a superior language anxiety in speaking skill. $\left(\mathrm{r}={ }^{-} .28 \& \&^{-} .25, \mathrm{p}=.001, \mathrm{n}=433\right)$.

In the Chinese setting with respect to the effect of language anxiety on students' achievement, not only matured students who either learn English as a subject or as a major were searched but also primary and secondary school students were considered as well. In Chan and Wu (2004) a sample of 601 fifth graders from 205 elementary schools in Taiwan were stratified, clustered and purposefully recruited to investigate the level of foreign language anxiety as well as the relationship between foreign language anxiety and achievement. The results not only showed the clear tendency of foreign language anxiety among elementary students but also confirmed the corresponding negative correlation results between foreign language anxiety and achievement with the measured students. Furthermore, Chen (2007) ascertained the relationship between foreign language anxiety and English achievement of bilingual elementary school students. The researcher studied the relationship between foreign language anxiety and English semester achievement. From two private schools in Taiwan, 222 of fifth and sixth graders were selected for the purpose of investigating the two variables. Even though correlation analysis revealed a slight variation between language anxiety and achievement in the diverse groups where fifth graders had greater significant negative correlation $\left(r={ }^{-} .392, p=.01, n=105\right)$ than sixth grade students $\left(r={ }^{-} .294, p=.01\right.$, $\mathrm{n}=120$ ), significant negative correlation between foreign language anxiety and English semester achievement for both grades in general were established $\left(\mathrm{r}={ }^{-} .289, \mathrm{p}=.01, \mathrm{n}=222\right)$.

In contrast, Lan (2010) studied the seventh grade students to investigate the level of foreign language anxiety and the relationship between foreign language anxiety and English learning achievement. Results of correlation analysis showed a significant inverse relationship between foreign language anxiety and English learning achievement $\left(\mathrm{r}={ }^{-} .57, \mathrm{p}=.01, \mathrm{n}=212\right)$.

Apart from the most educated languages to less studied languages, Aida (1994) explored the relationship between foreign language anxiety and performance, from a diverse sample of 64 native speakers of English, and 32 non-native speakers of English which included five Spanish speakers, six Chinese, fourteen Korean, five other Asian language speakers, and two other non-Asian speaker students. With regard to FLCAS, which was used to measure foreign language anxiety and final course grade in percentage, which was used to measure the students anxiety in Japanese language, correlation analysis revealed a significant, moderate negative correlation between foreign language anxiety of the heterogeneous sample and students' performance $\left(r={ }^{-} .38, p=.01\right.$, $n=96)$. 
Table 5. Systematic analysis of correlation between foreign language anxiety and achievement

\begin{tabular}{|c|c|c|c|c|c|c|c|c|}
\hline స్ర & Author & 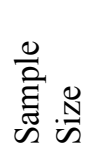 & 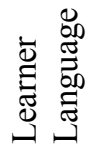 & 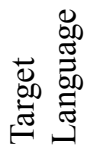 & Publication & Skill & $\mathrm{r}$ & $\mathrm{p}$ \\
\hline & \multirow{2}{*}{ Elaine K. Horwitz } & 35 & 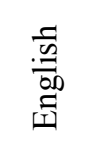 & 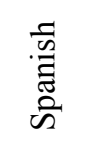 & $\begin{array}{l}\text { TESOL } \\
\text { Quarterly }\end{array}$ & Final Grade & -.49 & .003 \\
\hline \begin{tabular}{l}
$\infty$ \\
2 \\
\hdashline
\end{tabular} & & 32 & $\frac{\sqrt{n}}{: 00}$ & 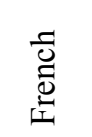 & $\begin{array}{l}\text { TESOL } \\
\text { Quarterly }\end{array}$ & Final Grade & -.54 & .001 \\
\hline ลू & $\begin{array}{lr}\text { Silvia } & \text { A. } \\
\text { Sanchez-Herrero, } & \text { Ma } \\
\text { Del Pilar Sanchez } & \end{array}$ & 205 & 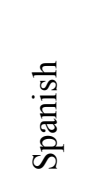 & $\frac{\sqrt{0}}{\stackrel{0}{00}}$ & $\begin{array}{l}\text { Education and } \\
\text { Psychological } \\
\text { Measurement }\end{array}$ & Achievement & \multicolumn{2}{|c|}{ Negative } \\
\hline ลू & Elaine M. Phillips & 44 & 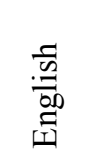 & 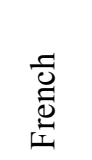 & $\begin{array}{l}\text { The Modern } \\
\text { Language } \\
\text { Journal }\end{array}$ & $\begin{array}{l}\text { Oral } \\
\text { Performance }\end{array}$ & -.40 & .01 \\
\hline รั & Yukie Aida & 96 & 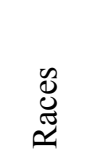 & 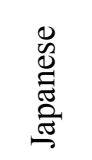 & $\begin{array}{l}\text { The Modern } \\
\text { Language } \\
\text { Journal }\end{array}$ & Performance & -.38 & .01 \\
\hline & \multirow{2}{*}{$\begin{array}{l}\text { R. C. Gardner, Paul F. } \\
\text { Tremblay, Anne-Marie } \\
\text { Masgoret }\end{array}$} & \multirow{2}{*}{102} & & & \multirow{2}{*}{$\begin{array}{l}\text { The Modern } \\
\text { Language } \\
\text { Journal }\end{array}$} & $\begin{array}{l}\text { Objective } \\
\text { Measure }\end{array}$ & -.66 & .001 \\
\hline$\hat{a}$ & & & $\frac{\sqrt{\infty}}{\stackrel{0}{0}}$ & 车 & & Final Grades & -.33 & .01 \\
\hline & \multirow[b]{2}{*}{ Yuh-Show Cheng } & \multirow[b]{2}{*}{433} & \multirow[b]{2}{*}{ 岕 } & \multirow[b]{2}{*}{$\frac{\sqrt{0}}{0.00}$} & \multirow[b]{2}{*}{ Thesis } & Speaking & -.28 & .001 \\
\hline$\stackrel{\infty}{2}$ & & & & & & Writing & -.25 & .001 \\
\hline
\end{tabular}

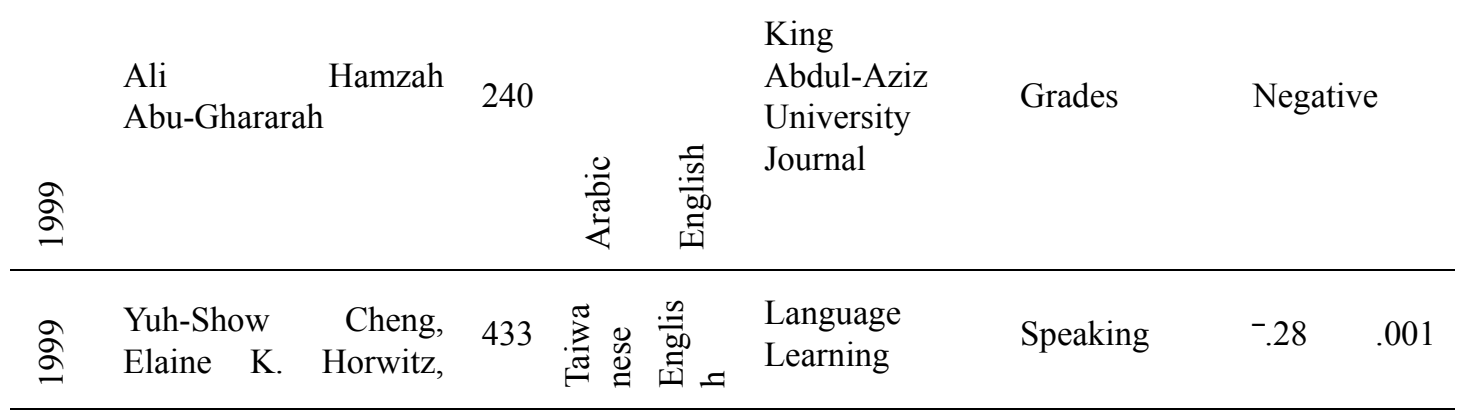


Diane L. Schallert

Writing $\quad-.25 \quad .001$

\begin{tabular}{|c|c|c|c|c|c|}
\hline Vanisa D. Sellers & 89 & 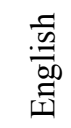 & 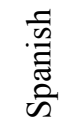 & Thesis & Reading \\
\hline
\end{tabular}

\begin{tabular}{|c|c|c|c|c|c|c|c|}
\hline & NiluferDalkilic & 115 & $\begin{array}{l}\frac{\bar{n}}{n} \\
\frac{a}{\Xi} \\
\vec{E}\end{array}$ & 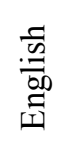 & $\begin{array}{l}\text { Dicle } \\
\text { University }\end{array}$ & Speaking & Negative \\
\hline & $\begin{array}{l}\text { Daniel Yu-Ching } \\
\text { Chan, Guo-Cheng Wu }\end{array}$ & 601 & 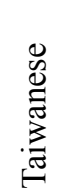 & $\begin{array}{l}\text { ज्ञ } \\
\text { ज0 } \\
\text { ज्ञ }\end{array}$ & $\begin{array}{l}\text { Journal of } \\
\text { National Taipei } \\
\text { Teachers } \\
\text { College }\end{array}$ & Achievement & Negative \\
\hline
\end{tabular}

\begin{tabular}{|c|c|c|c|c|c|c|c|c|}
\hline & Jian-Chang Cheng & 253 & $\begin{array}{l}\mathscr{U} \\
\stackrel{\Xi}{\Xi} \\
\bar{\Xi}\end{array}$ & 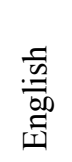 & Thesis & $\begin{array}{l}\text { Oral } \\
\text { Performance }\end{array}$ & -.174 & .001 \\
\hline$\stackrel{\overbrace{}}{\circ}$ & $\begin{array}{l}\text { Hyesook Park, Adam } \\
\text { R. Lee }\end{array}$ & 132 & 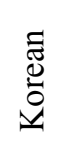 & 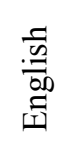 & $\begin{array}{l}\text { Conference } \\
\text { Paper }\end{array}$ & $\begin{array}{l}\text { Oral } \\
\text { Performance }\end{array}$ & -.321 & .001 \\
\hline
\end{tabular}

\begin{tabular}{|c|c|c|c|c|c|c|c|c|}
\hline 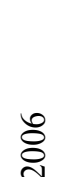 & $\begin{array}{l}\text { Jean T. } \\
\text { Wilson }\end{array}$ & Stephenson & 40 & 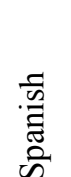 & 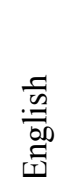 & Thesis & $\begin{array}{l}\text { Oral } \\
\text { Performance }\end{array}$ & -.494 \\
\hline
\end{tabular}

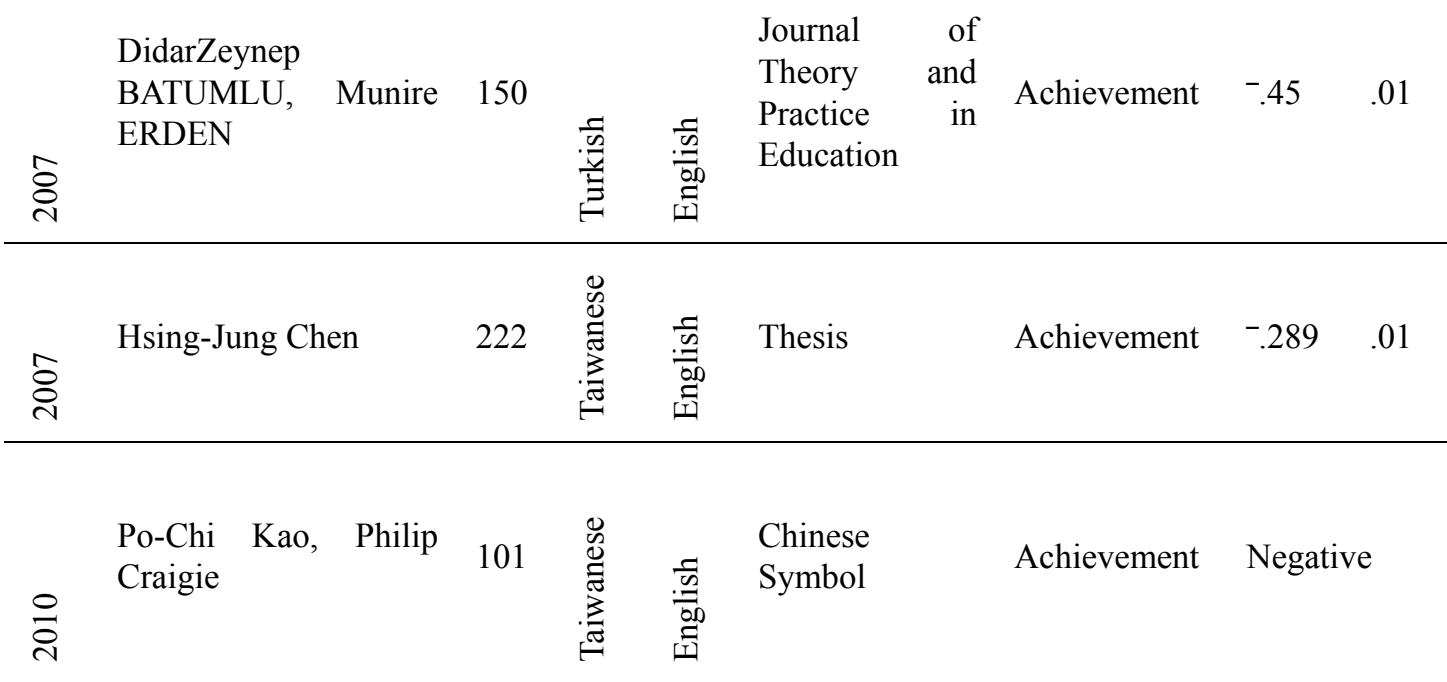




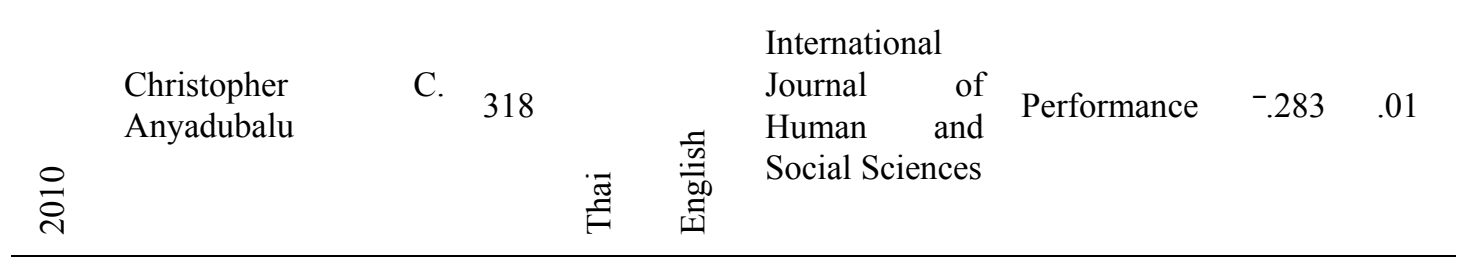

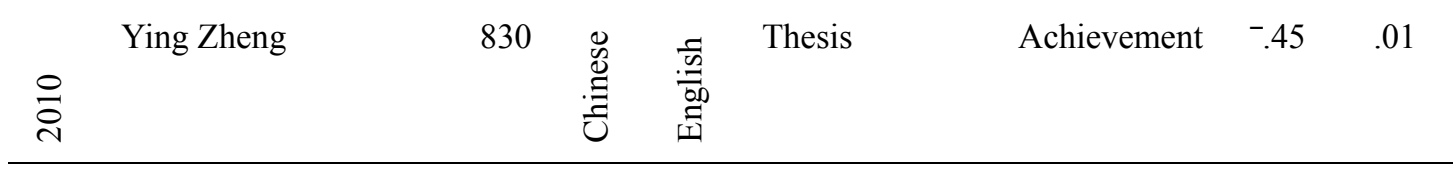

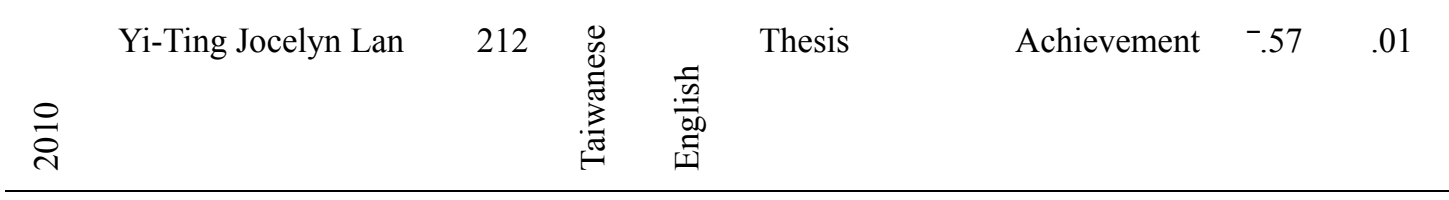

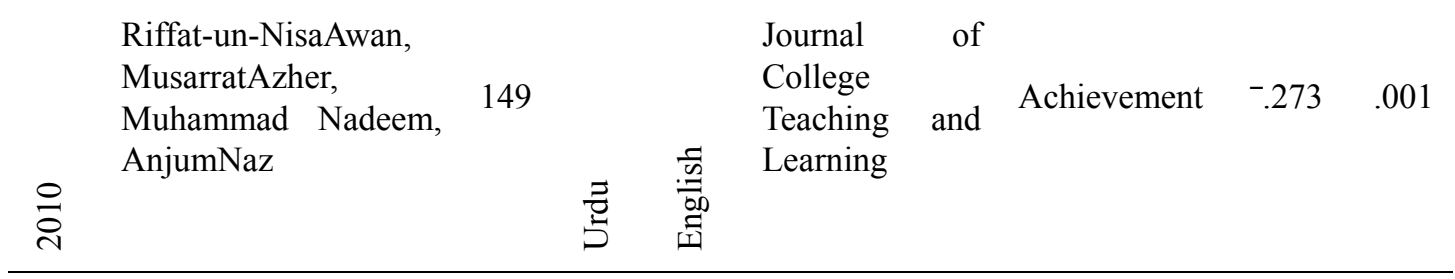

\begin{tabular}{|c|c|c|c|c|c|c|c|c|}
\hline$\overline{\vec{\nu}}$ & Wang Yao, Li Jingna & 92 & 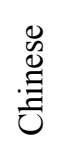 & 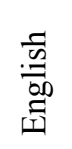 & IEEE & Reading & -.346 & .001 \\
\hline$\overline{\vec{\sim}}$ & $\begin{array}{l}\text { Elaine Hewitt, Jean } \\
\text { Stephenson }\end{array}$ & 40 & $\begin{array}{l}\text { ज़ } \\
\text { हूँ } \\
\text { के }\end{array}$ & $\begin{array}{l}\text { ज्ञ } \\
\frac{\sqrt[2]{0}}{80} \\
\text { 至 }\end{array}$ & $\begin{array}{l}\text { The Modern } \\
\text { Language } \\
\text { Journal }\end{array}$ & Oral & -.49 & .001 \\
\hline$\overline{\vec{\nu}}$ & Magdalena Szyszka & 48 & $\begin{array}{l}\frac{5}{0} \\
\frac{\pi}{0}\end{array}$ & $\begin{array}{l}\frac{.5}{6} \\
\frac{0}{60} \\
\overline{\mid 1}\end{array}$ & $\begin{array}{l}\text { Studies in } \\
\text { second } \\
\text { Language } \\
\text { Learning and } \\
\text { Teaching }\end{array}$ & Pronunciation & -.54 & .01 \\
\hline$\overline{\vec{d}}$ & $\begin{array}{l}\text { Zhongshe Lu, Meilhua } \\
\text { Liu }\end{array}$ & 934 & 迎 & 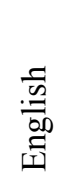 & $\begin{array}{l}\text { Journal of } \\
\text { Language } \\
\text { Teaching and } \\
\text { Research }\end{array}$ & Final Grades & -.317 & .01 \\
\hline 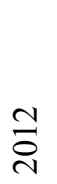 & $\begin{array}{l}\text { NaserAtasheneh, } \\
\text { Ahmad Izadi }\end{array}$ & 60 & 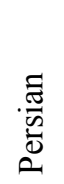 & $\begin{array}{l}. \overline{5} \\
.00 \\
\text { 至 }\end{array}$ & $\begin{array}{l}\text { English } \\
\text { language } \\
\text { Teaching }\end{array}$ & Listening & -.469 & .000 \\
\hline
\end{tabular}




\section{Conclusion}

To conclude, it is conspicuous that language anxiety has only a harmful side on learners' performance if the appropriate measure was used. In other words, foreign language anxiety affects the students' learning process and outcomes. Hitherto, not only the negative relationship between foreign language anxiety and achievement seems to vary according to the target language and specific skill (Horwitz, 2001) but also different levels of language proficiency, background, and stages play a role on the side effect of language anxiety on achievement. Table 5 above depicts the analysis of the correlation between foreign language anxiety and achievement. It shows that the significant negative relationship between foreign language anxiety and achievement mainly range from moderate to strong.

\section{Acknowledgment}

The authors would like to thank the editor and the anonymous reviewers for their valuable comments on the earlier version of this article. Special thanks go to Prof. Dr. Elain Horwitz for her insightful feedback.

\section{References}

Abu-Ghararah, A. H. (1999). Learning Anxiety and English Language Achievement of Male and Female Students of University and Secondary Stages in Al-Madinah Al-Munawwarah; A Comparative Research Study. King Abdulaziz University Journal, 12(1), 3-29. http://dx.doi.org/10.4197/Edu.12-1.2

Aida, Y. (1994). Examination of Horwitz, Horwitz, and Cope's Construct of Foreign Language Anxiety: The Case of Students of Japanese. The Modern Language Journal, 78(2), 155-168. http://dx.doi.org/10.1111/j.1540-4781.1994.tb02026.x

Anyadubalu, C. C. (2010). Self-Effecacy, Anxiety, and Performance in the English Language among Middle -School Students in English Language Program in Satri Si Suriyathai, bankok. International Journal of Human and Social Sciences, 2(3), 193-198.

Atasheneh, N., \& Izadi, A. (2012). The Role of Teachers in Reducing-Increasing Listening Comprehension Test Anxiety; A Case of Iranian EFL Learners. English language Teaching, 5(3), 178-187. http://dx.doi.org/10.5539/elt.v5n3p178

Awan, R.-u.-N., Azher, M., Nadeem, M., \& Naz, A. (2010). An Investigation of Foreign Language Classroom Anxiety and Its Relasionship with Students' Achievement. Journal of College Teaching and Learning, 7(11), $33-40$.

Batumlu, D. Z., \& Erden, M. (2007). The Relationship Between Foreign Language Anxiety and English Achievement of Yildiz Technology University School of Foreign Learners Preparatory Students. Journal of Theory and Practice in Education, 3(1), 24-38.

Brown, H. D. (2007). Principles of Language Learning and Teaching (5th ed.). United States of America: Pearson Longman.

Burden, P. (2004). The Teacher as Facilitator; Reducing Anxiety in the EFL University Classroom. JALT Hokkaido Journal, 8, 3-18.

Cao, Y. (2011). Copmarison of Two Models of Foreign language Classroon Anxiety Scale. Philippine ESL Journal, 7, 73-93.

Chan, D. Y., \& Wu, G. (2004). A Study of EFL Elementary School Students in Taipei Country. Journal of National Taipei Teachers College, 17(2), 287-320.

Chen, H. J. (2007). Foreign language Anxiety; A Study of Bilingual Elementary School. Master Degree, Chaoyang University of Technology. (etd-0620107-103007)

Cheng, J. (2005). The Relationship to Foreign Language Anxiety of Oral Performance Achievement, Teacher Characteristics and In-Class Activitis (Master's thesis). Ming Chuan University, Taiwan.

Cheng, Y. (1998). Examination of Two Anxiety Constructs; Second Language Classroom anxiety ans Second Language Writing Anxiety. Doctor of Philiosophy, The University of Texas at Austin, proQuest. (UMI 9837923)

Cheng, Y. S., Horwitz, E. K., \& Schallert, D. L. (1999). Language anxiety: Differentiating writing and speaking components. Language Learning, 49(3), 417-446. http://dx.doi.org/10.1111/0023-8333.00095

Chiang, Y. (2007). Connecting Two Anxiety Constructs; An Interdiscilinary Study of Foreign language Anxiety and interpretation Anxiety. Doctor of Philosophy, The University of Texas at Austin, ProQuest. (UMI 
3249927)

Dalkilic, N. (2001). The Role of Foreign Language Classroom Anxiety in English Speaking Courses. ENSTiTÜ DERGISI, 8(8), 70-82. Retrieved from http://sosyalbilimler.cukurova.edu.tr/dergi.asp?dosya $=366$

Gardner, R. C., Tremblay, P. F., \& Masgoret, A.-M. (1997). Towards a Full Model of second Language Learning; An Empirical Investigation. The Modern Language Journal, 81(3), 344-362. http://dx.doi.org/10.1111/j.1540-4781.1997.tb05495.x

Hewitt, E., \& Stephenson, J. (2011). Foreign Language Anxiety and Oral Exam Performance: A Replication of Phillips's MLJ Study. The Modern Language Journal, 96(2). $\mathrm{http}: / / \mathrm{dx}$. doi.org/10.1111/j.1540-4781.2011.01174.x

Horwitz, E. K. (1986). Preliminary Evidence for the Reliability and Validity of a Foreign-Language Anxiety Scale. Tesol Quarterly, 20(3), 559-562. http://dx.doi.org/10.2307/3586302

Horwitz, E. K. (2001). Language Anxiety and Achievement. Annual Review of Applied Linguistics, 21, 112-127. http://dx.doi.org/10.1017/S0267190501000071

Horwitz, E. K., Horwitz, M. B., \& Cope, J. (1986). Foreign-Language Classroom Anxiety. Modern Language Journal, 70(2), 125-132. http://dx.doi.org/10.1111/j.1540-4781.1986.tb05256.x

Kao, Po-C., \& Craigie, P. (2010). Foreign Language Anxiety and English Achievement in Taiwanese Undergraduate English-Major Students; An Empirical Study (pp. 49-62).

Lan, Yi-T. J. (2010). A Study of Taiwanese 7th Graders' Foreign Language Anxiety, Beliefs about Language Learning and its Relationship with their English Achievement (Master's thesis). Ming Chuan University, Taiwan.

Lee, Mei-L. (2011). Differences in the Learning Anxieties Affecting College Freshman Students of EFL. In R. Jaidev, M. L. C. Sadorra, W. J. Onn, L. M. Cherk, \& B. P. Lorente (Eds.), Global Perspectives, Local Initiatives (1st ed., pp. 169-182). National University of Singapore: Centre for English Language Communication.

Liu, M., \& Huang, W. (2011). An Exploration of Foreign Language Anxiety and English Motivation. Education Research International, 1-8. http://dx.doi.org/10.1155/2011/493167

Lu, Z., \& Liu, M. (2011). Foreign language Anxiety and Strategy Use; A Study with Chinese Undergraduate EFL Learners. Journal of Language Teaching and Research, 2(6), 1298-1305. http://dx.doi.org/10.4303/jltr.2.6.1298-1305

McCroskey, J. C. (1970). Measures of Communication-Bound Anxiety. Speech Monographs, 37, 269-277. http://dx.doi.org/10.1080/03637757009375677

Mulatu, M. S. (2002). Psychometric Properties of Scores on The Preliminary Amharic Version of The State-trait Anxiety Inventory in Ethiopia. Education and Psychological Measurment, 62(1), 130-146. http://dx.doi.org/10.1177/0013164402062001009

Olivares-Cuhat, G. (2010). Relative Importance of Learning Variables on L2 Performance. Linguistik online, 43(3), 99-116.

Park, H., \& Lee, A. R. (2005). L2 Learners' Anxiety, Self-Confidence and Oral Performance. Paper presented at the The Pan-Pacific Association of Applied Linguistics (PAAL), Japan.

Perez-Paredes, P. F., \& Martinez-Sanchez, F. (2000-2001). A Spanish Version of the Foreign Language Classroom Anxiety Scale; Revisiting Aid's Factor Analysis. RESLA, 14, 337-352.

Phillips, E. M. (1992). The Effects of Language Anxiety on Students' Oral Test Performance and Attitudes. The Modern Language Journal, 76(1), 14-26. http://dx.doi.org/10.1111/j.1540-4781.1992.tb02573.x

Sanchez-Herrero, S. A., \& Sanchez, M. D. P. (1992). The Predictive Validation of an Instrument Designed to Measure Student Anxiety in Learning a Foreign Language. Education and Psychological Measurment, 52, 961-966. http://dx.doi.org/10.1177/001364492052004019

Scovel, T. (1978). The Effect of Affect: A Review of the Anxiety Literature. Language Learning, 28, 129-142. http://dx.doi.org/10.1111/j.1467-1770.1978.tb00309.x

Sellers, V. D. (1999). On The Relationship between Anxiety and Reading in Spanish as a Foreign Language. Doctor of Philosophy, The Pennsylvania State University, UMI Company. (UMI 9915946) 
Spielberger, C. D., Gorsuch, R. L., Lushene, R., Vagg, P. R., \& Jacobs, G. A. (1983). Manual of the State-Trait Anxiety Inventory. Palo Alto: Consulting Psychologists Press.

Spielberger, C. D., Reheiser, E. C., Owen, A. E., \& Sydeman, S. J. (2004). Measuring the Psychological Vital Signs of Anxiety, Anger, Depression, and Curiosity in Treatment Planning and Outcomes Assessment. In M. E. Maruish (Ed.), The Use of Psychological Testing for Treatment Planning and Outcomes Assessment Vol. 3 (3th ed., pp. 421-447). London: Lawrence Erlbaum Associate, Inc.

Szyszka, M. (2011). Foreign Language Anxiety and Self-perceived English Pronounciation Competence. Studies in second Language Learning and Teaching, 1(2), 283-300.

Toth, Z. (2008). A Foreign Language Anxiety Scale for Hungarian Learners of English. WoPaLP, 2, 55-78.

Trang, T. T. T. (2012). A Review of Horwitz, Horwitz and Cope Theory of Foreign Language Anxiety and the Challenges to the Theory. English Language Teaching, 5(1), 69-75. http://dx.doi.org/10.5539/elt.vn1p69

Watson, D., \& Friend, R. (1969). Measurement of Social-Evauative Anxiety. Journal of Consulting and Clinical psychology, 33, 448-457. http://dx.doi.org/10.1037/h0027806

Wilson, J. T. S. (2006). Anxiety in Learning English as a Foreign Language; Its Associations with Students Variables, with Overall Proficiency, and with Performance in an Oral Test. La Directora, Universidad De Granada.

Yao, W., \& Jingna, L. (2011). The Interference of Foreign Language Anxiety in the Reading Comprehension of Agricultural Engineering Students. IEEE, 660-663.

Zheng, Y. (2010). Chinese University Students' Motivation, Anxiety, Global Awareness, Linguistic Confidence, and English Test Performance (Doctoral dissertation) . Queen's University, Canada, Library and Archives Canada. Retrieved from http://hdl.handle.net/1974/5378

Zulkifli, V. (2007). Language Classroom Anxiety; A Comparative Study of ESL Learners. Asian Journal of university Education, 3(2), 75-99.

\section{Note}

Note 1. It seems that the same study in a different type of publication corresponding with a different researcher was conducted. 